\title{
Bacterial Degradation of N-Lauroyl-L-valine ${ }^{\dagger}$
}

\author{
Toshiro ShIDA, Yasuo Homma and Tomomasa Misato \\ Central Research Laboratories, Ajinomoto Co., Inc., Kawasaki and \\ The Institute of Physical and Chemical Research, Wako-shi, Saitama, Japan
}

Received September 18, 1972

\begin{abstract}
Studies were conducted on the degradation of N-lauroyl-L-valine by type cultured bacteria. Many strains could utilize sodium N-lauroyl-L-Valinate as carbon and nitrogen sources for their growth. Metabolism of N-lauroyl-L-valine was investigated in detail using $P$ s. aeruginosa AJ2116. Lauric acid was identified by gas chromatography suggesting cleavage of $\mathrm{N}$-acyl linkage in N-lauroyl-L-valine.

Lauric acid might be metabolized to capric acid $\left(\mathrm{C}_{10}\right)$ and caprylic acid $\left(\mathrm{C}_{8}\right)$ becuase the accumulated substances gave nearly identical peaks with those of authentic fatty acids on gas chromatograms. The experiment using $\mathrm{N}$-lauroyl-L-valine $\left({ }^{14} \mathrm{C}\right)$ indicated that ${ }^{14} \mathrm{CO}_{2}$ was produced as a final product. Valine was not detected because it might be metabolized very rapidly immediately after its release.

It was supposed that the enzymes or enzyme systems degrading N-lauroyl-L-valine might be constitutive from the experiment using two kinds of cells grown in the medium containing $\mathrm{N}$-lauroyl-L-valine or nutrient broth.
\end{abstract}

Agents responsible to degradation of pesticides under natural environment are classified into two groups; physical ones such as light, temperature and $\mathrm{pH}$, and biological ones such as soil microorganisms and plants. Among them the degradation by soil microorganisms is very important because the greater part of pesticide used on plants penetrates into the soil.

In the previous paper, ${ }^{1)}$ it was reported that several amino acid derivatives, as new pesticides, showed some preventive effect against rice blast. Among them N-lauroyl-L-valine (hereafter referred to as No. 5) was most effective to the disease. In this paper, aerobic bacterial degradation of No. 5 in pure culture using type culture is investigated.

\section{MATERIALS AND METHODS}

Microorganisms. Eighty four kinds of aerobic bacteria belonging to 16 genera and 56 species which were obtained from Central Research Laboratories,

$\uparrow$ Control of Plant Diseases by Amino Acid Derivatives. Part II. A brief account of this paper was presented by T. Misato at the U.S.-Japan Seminar on environmental toxicology of pesticides, Oiso, Japan, October 28, 1971.
Ajinomoto Co., Inc. (Kawasaki, Japan) were used throughout this work.

\section{Cultivation methods}

1) Test tube scale cultivation. The medium for the test tube cultivation contained $0.1 \% \mathrm{KH}_{2} \mathrm{PO}_{4}$, $0.04 \% \quad \mathrm{MgSO}_{4} \cdot 7 \mathrm{H}_{2} \mathrm{O}, 1 \%$ sodium N-lauroyl-Lvalinate (hereafter referred to as No, $5-\mathrm{Na}$ ) or Blasticidin S obtained from Kaken Chemical Co., Ltd. and $0.05 \%$ Bacto yeast extract (Difco), and the $\mathrm{pH}$ was adjusted to 7.0 . The medium $(10 \mathrm{ml})$ was added to a test tube $(60 \mathrm{ml}$ vol), and sterilized by autoclaving at $120^{\circ} \mathrm{C}$ for $20 \mathrm{~min}$.

A loopful of cells grown on nutrient agar slant at $30^{\circ} \mathrm{C}$ for $24 \mathrm{hr}$ was inoculated to the medium. The cultivation was performed at $28^{\circ} \mathrm{C}$ for $48 \mathrm{hr}$. The state of growth was recorded according to the following signs.

$\begin{array}{cc}\text { Sign } & \begin{array}{c}\text { Optical density of } \\ \text { the medium at } 562 \mathrm{~m} \mu\end{array} \\ - & \text { less than } 0.003 \\ + & \text { less than } 0.040 \\ + & \text { less than } 0.310 \\ ++ & \text { less than } 0.405 \\ +++ & \text { less than } 0.530 \\ ++++ & \text { less than } 0.920\end{array}$

2) Flask scale cultivation. The medium contained $0.1 \% \mathrm{KH}_{2} \mathrm{PO}_{4}, 0.04 \% \quad \mathrm{MgSO}_{4} \cdot 7 \mathrm{H}_{2} \mathrm{O}, 0.03 \%$ $\left(\mathrm{NH}_{2}\right)_{2} \mathrm{CO}, 0.03 \%\left(\mathrm{NH}_{4}\right)_{2} \mathrm{SO}_{4}, 3 \% \mathrm{CaCO}_{3}, 3 \% \mathrm{No} .5-$ $\mathrm{Na}, 0.05 \%$ Bacto yeast extract (Difco) and the $\mathrm{pH}$ was 
<smiles>CCCCCCCCC(C)C(NC(=O)CC)C(=O)O</smiles>

FIG, 1. Labeled N-Lauroyl-L-valine.

adjusted to 7.0 . The medium $(50 \mathrm{ml})$ was added to a shaking flask $(500 \mathrm{ml})$ and sterilized by autoclaving at $120^{\circ} \mathrm{C}$ for $20 \mathrm{~min}$. Cultivation was performed at $35^{\circ} \mathrm{C}$. Cultures were diluted five times with $0.1 \mathrm{~N}$ $\mathrm{HCl}$ and optical density measured at $562 \mathrm{~m} \mu$ by a Hitach/Model 101 Spectrophotometer.

Assay of ${ }^{14} \mathrm{CO}_{2}$ produced from $N$-lauroyl-L-yaline. Structural formula of N-lauroyl-L-valine $\left({ }^{14} \mathrm{C}\right)$ synthesized chemically from $\mathrm{L}$-valine and lauric acid-14 $\mathrm{C}$ was indicated in Fig. 1. Cells which were cultivated in the medium containing $3 \% \mathrm{No} .5-\mathrm{Na}, 0.1 \% \mathrm{KH}_{2} \mathrm{PO}_{4}$, $0.04 \% \mathrm{MgSO}_{4} \cdot 7 \mathrm{H}_{2} \mathrm{O}, 0.05 \%$ Bacto yeast extract (Difco) and $3 \% \mathrm{CaCO}_{3}, \mathrm{pH} 7.0$, in a shaking flask $(500 \mathrm{ml}$ vol), at $35^{\circ} \mathrm{C}$ for $72 \mathrm{hr}$ were washed three times with $\mathrm{M} / 15$ phosphate buffer solution, and suspended in the same buffer solution. Optical density at $562 \mathrm{~m} \mu$ of cell suspension was adjusted to 1.00. Cell suspension $(2.5 \mathrm{ml})$ and $0.3 \mathrm{ml}$ of $\mathrm{N}$-lauroyl-L-valine $\left({ }^{14} \mathrm{C}\right)$ solution $(93135 \mathrm{cpm})$ were mixed in a Warburg's vessel.

Incubation was performed at $35^{\circ} \mathrm{C}$ for $18 \mathrm{hr}$ and ${ }^{14} \mathrm{CO}_{2}$ produced was trapped in $0.5 \mathrm{ml}$ of ethanolamine in a center well of the vessel. Radioactive carbon dioxide dissolved in the buffer solution was gassified by adding $0.5 \mathrm{ml}$ of $1 \mathrm{~N} \mathrm{H}_{2} \mathrm{SO}_{4}$ in a side arm to the buffer solution after incubation. Radioactivity of ${ }^{14} \mathrm{CO}_{2}$ in ethanolamine was counted in a liquid scintillation counter. Quantitative determination of No.5$\mathrm{Na}$ was made colorimetrically by pinacyanol chloride$\mathrm{HCl}_{3}$ method modified by Kamimura. ${ }^{3 \prime}$

After incubation cells and residual N-lauroyl-Lvaline $\left({ }^{1} \mathrm{C}\right)$ mixture in the vessel were oxidized according to the method of Baba et al.,2) and then the radioactivity of ${ }^{14} \mathrm{CO}_{2}$ produced was measured by a liquid scintillation counter.

Quantitative determination of L-valine. The amino acid was determined quantitatively by microbial bioassay method.

Experiment of consumption of $N$-lauroyl-L-valine by Ps. aeruginosa AJ2116 during incubation. Cells which were grown in the nutrient broth at $35^{\circ} \mathrm{C}$ for $42 \mathrm{hr}$ or in the medium containing $1 \%$ No, $5-\mathrm{Na}, 0.1 \%$ $\mathrm{KH}_{2} \mathrm{PO}_{4}, 0.04 \% \quad \mathrm{MgSO}_{4} \cdot 7 \mathrm{H}_{2} \mathrm{O}, 0.05 \%$ Bacto yeast extract (Difco) and $3 \% \mathrm{CaCO}_{3}, \mathrm{pH} 7.0$ in a shaking flask $\left(500 \mathrm{ml}\right.$ vol) at $35^{\circ} \mathrm{C}$ for $72 \mathrm{hr}$ were suspended in $10 \mathrm{ml}$ of $\mathrm{M} / 15$ phosphate buffer (pH 7.0) after washing three times by the same buffer. Optical density at $562 \mathrm{~m} \mu$ of the cell suspension in five fold incubation broth was adjusted to 0.450 . Incubation was perform- ed at $35^{\circ} \mathrm{C}$ with shaking. After incubation cells were removed by centrifugation, and amount of No. 5 remained in the supernatant was determined quantitatively.

Identification of No. 5 by gas chromatography. Trimethylsililation was carried out for the preparation of samples for gas chromatography. In a test tube $0.5 \mathrm{ml}$ of incubation medium, $1 \mathrm{ml}$ of pyridine, $1 \mathrm{ml}$ of N.O-bis-(trimethylsilyl) acetamide and one or two drops of trimethyl-chlorosilane were mixed. The tube was heated in a mantle heater for about 10 min till pyridine boiled. An aliquot $(3 \mu 1)$ of the mixture was injected into gas chromatograph. Peaks were tentatively identified by comparison of the retention time. Conditions of gas chromatography; apparatus, $\mathrm{F}$ and $\mathrm{M}$ Model 402 gas chromatography, glass column, $4 \% \mathrm{SE}-30$ on Diatoport $\mathrm{S}$ ( $1 / 4 \times 4$ inches), column temperature, $180^{\circ} \mathrm{C}$, carrier gas, Helium, flow rate, $60 \mathrm{ml} / \mathrm{min}$ and detection method, hydrogen flame ionization.

\section{RESULTS}

1) Utilization of $\mathrm{No}$. 5- $\mathrm{Na}$ as carbon and nitrogen sources by aerobic bacteria

Utilization of No. 5- $\mathrm{Na}$ by aerobic bacteria was tested in the test tube scale. As shown in Tables I, II and III, many strains of aerobic bacteria utilized No. 5- $\mathrm{Na}$ for their growth. Generally, gram negative bacteria belonging to Pseudomonas, Achromobacter and Enterobacterium utilized sodium N-lauroyl-L-valinate more actively than gram positive ones. But No. 5-Na utilizing bacteria are not limited to specific genera or species, but distributed widely in the natural world.

In case of experiments using Blasticidin $\mathrm{S}$ instead of No. $5-\mathrm{Na}$, most strains could not utilize the antibiotic by this method. These data indicate that No. 5- Na can be degraded very rapidly by many bacterial strains.

\section{2) Decomposition of No. 5-Na by Pseudo- monas aeruginosa $\mathrm{AJ} 2116$}

As stated above, many strains of bacteria utilized actively No. 5-Na. Metabolism of No. $5-\mathrm{Na}$ by $P$ s. aeruginosa $\mathrm{AJ} 2116$ was investigated in the flask scale. Table IV shows growth of $P_{s}$. aeruginosa AJ2116 in the medium containing No. 5- Na and consumption of 
Table I. Degradative Spectrums of Aerobic Bacteria Against N-Lauroyl-l-valine (No. 5)

\begin{tabular}{|c|c|c|c|c|}
\hline \multirow[b]{2}{*}{ Microorganisms } & \multirow[b]{2}{*}{ AJ No. } & \multirow[b]{2}{*}{ Other No. } & \multicolumn{2}{|c|}{ The state of growth } \\
\hline & & & No. 5 & $\mathrm{BCS}$ \\
\hline Pseudomonas aeruginosa & 2116 & ATCC 10145 & ++++ & - \\
\hline Pseudomonas ovalis & 2011 & IAM 1002 & $++t$ & - \\
\hline Pseudomonas desmolytica & 2003 & IAM 1089 & ++ & - \\
\hline Pseudomonas syncyanea & 2029 & IFO 3750 & ++ & - \\
\hline Pseudomonas fluorescens & 2035 & IAM 1154 & $++t$ & - \\
\hline Pseudomonas synxantha & 2038 & IFO 3913 & ++ & - \\
\hline Pseudomonas stutzeri & 2056 & IAM 1504, ATCC 9114 & $+t$ & - \\
\hline Pseudomonas putrefccins & 2059 & IAM 1510, ATCC 12099 & - & - \\
\hline Pseudomonas putrefacisns & 2060 & & - & - \\
\hline Pseudomonas mildenbergii & 2063 & IAM 1505, ATCC 795 & +++ & - \\
\hline Pseudomonas chlororaphis & 2068 & IAM 1515, ATCC 9447 & $+t+$ & - \\
\hline Pseudomonas taetrolens & 2069 & IAM 1653, IFO 3460 & $+t$ & - \\
\hline Pseudomonas perolens & 2077 & ATCC 10757 & ++ & - \\
\hline Pseudomonas maltophila & 2082 & ATCC 13637 & ++ & - \\
\hline Pseudomonas maltophila & 2090 & $M-126$ & ++ & - \\
\hline Pseudomonas maltophila & 2276 & IAM 1438 & ++ & - \\
\hline Pseudomonas maltophila & 2311 & & $+t$ & - \\
\hline Pseudomonas maltophila & 2313 & & ++ & - \\
\hline Pseudomonas straminea & 2122 & $C B-12$ & + & - \\
\hline Pseudomonas straminea & 2124 & IAM 1598 & + & - \\
\hline Pseudomonas lacunogenes & 2197 & IAM 1568 & - & - \\
\hline Pseudomonas lacunogenes & 2199 & IAM 1590 & - & - \\
\hline Pseudomonas lacunogenes & 2217 & IAM 1532 & - & - \\
\hline Pseudomonas azotoformans & 2241 & IAM 1487 & +++ & - \\
\hline Pseudomonas nitroreducens & 2242 & IAM 1408 & $+t+$ & + \\
\hline Pseudomonas nitroreducens & 2244 & IAM 1430 & $+t+$ & - \\
\hline Pseudomonas nitroreducens & 2245 & IAM 1443 & +++ & - \\
\hline
\end{tabular}

this compound. The consumption of No. 5$\mathrm{Na}$ was low in the absence of $\left(\mathrm{NH}_{4}\right)_{2} \mathrm{SO}_{4}$ and $\left(\mathrm{NH}_{2}\right)_{2} \mathrm{CO}$.

3) Investigation whether the decomposition of No. 5- Na by Ps. aeruginosa AJ2116 was performed by constitutive enzyme systems or inductive ones

Generally the decomposition of pesticides is performed by inductive enzyme systems, that is, the decomposition is antidotal. It was investigated whether the decomposition of No. $5-\mathrm{Na}$ by $P_{s}$. aeruginosa AJ2116 was performed antidotally or not. Two kinds of cells grown in the medium containing No. 5$\mathrm{Na}$ and in the nutrient broth were used. Figure 2 shows residual curves of No. 5- Na in the incubation medium by two kinds of cells. The tendency of residual curves of No. $5-\mathrm{Na}$ was almost same between two kinds of cells.

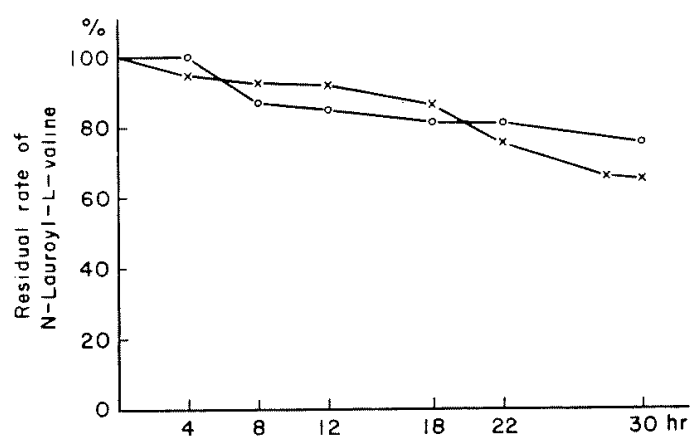

FIG. 2. Comsumption of N-Lauroyl-L-valine by $P S$. aeruginosa AJ2116 during Incubation in Phosphate Buffer.

$x-x$ by cells grown in the nutrient broth

0 - $O$ by cells grown in the medium containing N-lauroyl-L-valine

From these results the enzymes or enzyme systems involved in the degradation of No. 5$\mathrm{Na}$ by this strain may be recognized as constitutive. 
Table II. Degradative Spectrums of Aerobic Bacteria against N-Lauroyl-l-valine (No. 5)

\begin{tabular}{|c|c|c|c|c|}
\hline \multirow[b]{2}{*}{ Microorganisms } & \multirow[b]{2}{*}{ AJ No. } & \multirow[b]{2}{*}{ Other No. } & \multicolumn{2}{|c|}{ The state of growth } \\
\hline & & & No. 5 & $\mathrm{BcS}$ \\
\hline Achromobacter liquidum & 2385 & IAM 1667, IFO 3084 & - & - \\
\hline Achromobacter xerosis & 2398 & CCM 71-A & + & - \\
\hline Achromobacter delmarvae & 2405 & M-13 & - & - \\
\hline Achromobacter delmarvae & 2390 & IAM 2390 & - & - \\
\hline Achromobacter pestifer & 2412 & $\mathrm{~N}-10-3$ & ++ & - \\
\hline Achromobacter winogratski & 2427 & NCIB 9017 & \pm & - \\
\hline Achromobacter lwoffi & 2428 & NCIB 9020 & \pm & - \\
\hline Achromobacter delicatulus & 2429 & NCIB 9302 & + & - \\
\hline Flavobacterium citreum & 2452 & IAM 1158 & + & - \\
\hline Flavobacterium gasogenes & 2454 & & + & - \\
\hline Flavobacterium rigense & 2455 & IAM 1238 & - & - \\
\hline Flavobacterium arborescens & 2489 & ATCC 4358 & ++ & - \\
\hline Flavobacterium aquatile & 2513 & ATCC 11947 & \pm & - \\
\hline Enterobacter aerogenes & 2631 & 24PDI & - & - \\
\hline Enterobacter aerobacter & 2646 & IAM 1133, ATCC 8329 & ++ & - \\
\hline Enterobacter cloacae & 2655 & IAM 1064 & ++ & \pm \\
\hline Enterobacter cloacae & 2659 & 25HPI & - & - \\
\hline Escherichia coli & 2632 & & ++ & - \\
\hline Escherichia coli & 2617 & ATCC 11775 & ++ & - \\
\hline Erwinia herbicola & 2669 & $\mathrm{~K}-59-1$ & ++ & - \\
\hline Erwinia herbicola & 2670 & $\mathbf{K}-59-2-1$ & - & - \\
\hline Proteus vulgaris & 2764 & IAM 1025 & - & - \\
\hline Proteus vulgaris & 2766 & & - & - \\
\hline Proteus vulgaris & 2773 & & - & - \\
\hline Aglobacterium radiobacter & 2781 & IAM 1526, ATCC 4718 & ++ & - \\
\hline
\end{tabular}
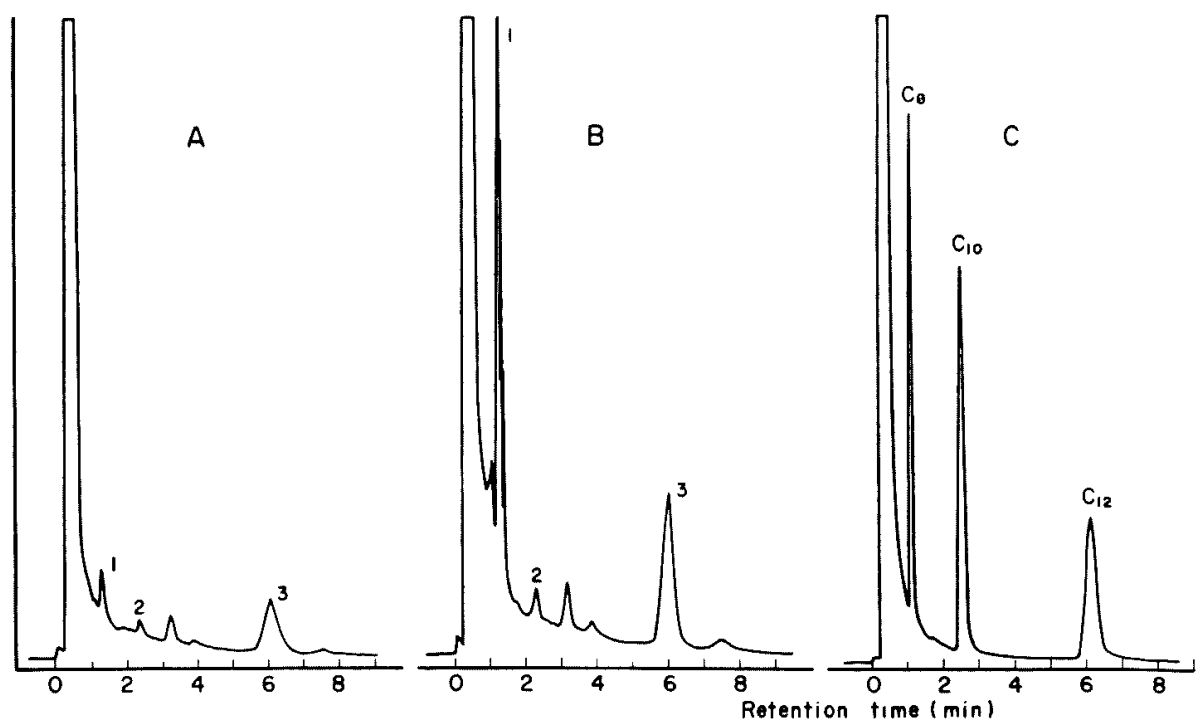

FIG. 3. Gas Chromatograms of Incubation Broth Containing Sodium N-Lauroyl-L-valinate by PS. aeruginosa AJ 2116.
A: Broth before incubation.
B: Broth after incubation for $14 \mathrm{hr}$.

C: Authentic caprylic acid $\left(\mathrm{C}_{8}\right)$, capric acid $\left(\mathrm{C}_{10}\right)$, and lauric acid $\left(\mathrm{C}_{12}\right)$

Column: $4 \%$ SE-30 on Diatoport S $1 / 4$ Inch tem. $180^{\circ} \mathrm{C}$. 
Table III. Degradatrve Spectrums of Aerobic Bacteria against N-Lauroyl-L-valine (NO. 5)

\begin{tabular}{|c|c|c|c|c|}
\hline \multirow[b]{2}{*}{ Microorganisms } & \multirow[b]{2}{*}{ AJ No. } & \multirow[b]{2}{*}{ Other No. } & \multicolumn{2}{|c|}{ The state of growth } \\
\hline & & & No. 5 & $\mathrm{BcS}$ \\
\hline Micrococcus lysodeikticus & 1002 & IAM 1050, IFO 3333 & + & - \\
\hline Micrococcus lysodeikticus & 1009 & IAM 1313, ATCC 4698 & + & - \\
\hline Micrococcus varians & 1005 & IAM 1314, ATCC 399 & + & - \\
\hline Micrococcus conglomeratus & 1015 & IAM 1448 & - & - \\
\hline Micrococcus flavus & 1021 & ATCC 400 & + & \pm \\
\hline Micrococcus luteus & 1074 & CCM 132 & + & - \\
\hline Micrococcus luteus & 1003 & ATCC 398 & + & - \\
\hline Serratia marcescens & 2682 & IAM 1021 & ++ & - \\
\hline Serratia marcescens & 2689 & IAM 1223 & ++ & - \\
\hline Staphylococcus aureus & 1056 & IAM 1011, ATCC 6538 & + & - \\
\hline Staphylococcus aureus & 1057 & IAM 1058 & + & - \\
\hline Sarcina lutea & 1217 & ATCC 272 & + & - \\
\hline Sarcina lutea sub Sp. flava & 1026 & IAM 1491 & + & - \\
\hline Bacillus subtilis & 1235 & IAM 1069, ATCC 6633 & - & - \\
\hline Bacillus subtilis & 1240 & IAM 1214, IFO 3027 & - & - \\
\hline Bacilus subtillis & 1246 & IAM 1108 & - & - \\
\hline Bacillus subtilis & 1308 & IAM 1225 & - & - \\
\hline Bacillus subtilis & 1311 & IAM 1521 & - & - \\
\hline Bacillus subtilis & 1315 & ATCC 6051 & - & - \\
\hline Bacillus cereus & 1264 & IAM 1029 & + & - \\
\hline Bacillus megatherium & 1277 & IAM 1166 & - & - \\
\hline Bacillus megatherium & 1273 & IAM 1073 & - & - \\
\hline Bacillus polymyxa & 1278 & IAM 1210 & - & - \\
\hline $\begin{array}{l}\text { Corynebacterium } \\
\text { hydrocarboclastus }\end{array}$ & 1379 & IAM 1399 & + & - \\
\hline $\begin{array}{l}\text { Corynebacterium } \\
\text { hydrocarboclastus }\end{array}$ & 1381 & IAM 1428 & + & - \\
\hline $\begin{array}{l}\text { Corynebacterium } \\
\text { hydrocarboclastus }\end{array}$ & 1389 & IAM 1400 & + & \pm \\
\hline Corynebacterium equi & 1376 & & + & \pm \\
\hline Arthrobacter ureafaciens & 1436 & IAM 1390 & - & - \\
\hline Arthrobacter globiformis & 1422 & ATCC 8010 & - & - \\
\hline Brevibacterium acetylicum & 1441 & IAM 1651, ATCC 953 & \pm & - \\
\hline Brevibacterium ammoniagenes & 1443 & IAM 1641, ATCC 6871 & + & - \\
\hline Brevibacterium lypolyticum & 1450 & IAM 1398 & + & - \\
\hline
\end{tabular}

Table IV. Growth of Ps. aeruginosa AJ 2116 in the Medium Containing SOdIUM N-Lauroyl-L-VAlinate and Its CONSUMPTION

\begin{tabular}{ccccc}
\hline $\begin{array}{c}\text { No. of } \\
\text { Experiment }\end{array}$ & hr & $\begin{array}{c}\text { Growth } \\
(\text { O.D. at } 562 \mathrm{~m} \mu)\end{array}$ & $\begin{array}{c}\text { Residual No. 5 } \\
(\mathrm{mg} / \mathrm{dl})\end{array}$ & $\begin{array}{c}\text { No. 5 } \\
\text { consumed }(\%)\end{array}$ \\
\hline 1 & 0 & 0 & 2820 & 0 \\
& 96 & 1.900 & 680 & 75.9 \\
$2^{a)}$ & 0 & 0 & 2664 & 0 \\
& 96 & 1.500 & 1246 & 53.3
\end{tabular}

a) $\left(\mathrm{NH}_{4}\right)_{2} \mathrm{SO}_{4}$ and $\left(\mathrm{NH}_{2}\right)_{2} \mathrm{CO}$ were omitted from the medium

b) sodium $\mathrm{N}$-Lauroyl-L-valinate

4) Identification of products of No. 5

Quantitative analysis of substances formed during cultivation of Ps. aeruginosa AJ2116 with No. 5 was investigated by gas chromatography. As shown in Fig. 3, lauric acid $\left(\mathrm{C}_{12}\right)$ was detected in the medium after incubation 
Table V. Production of ${ }^{14} \mathrm{CO}_{2}$ from N-Lauroyl-L-Valine( $\left({ }^{14} \mathrm{C}\right)$ By Ps. aeruginosa AJ 2116

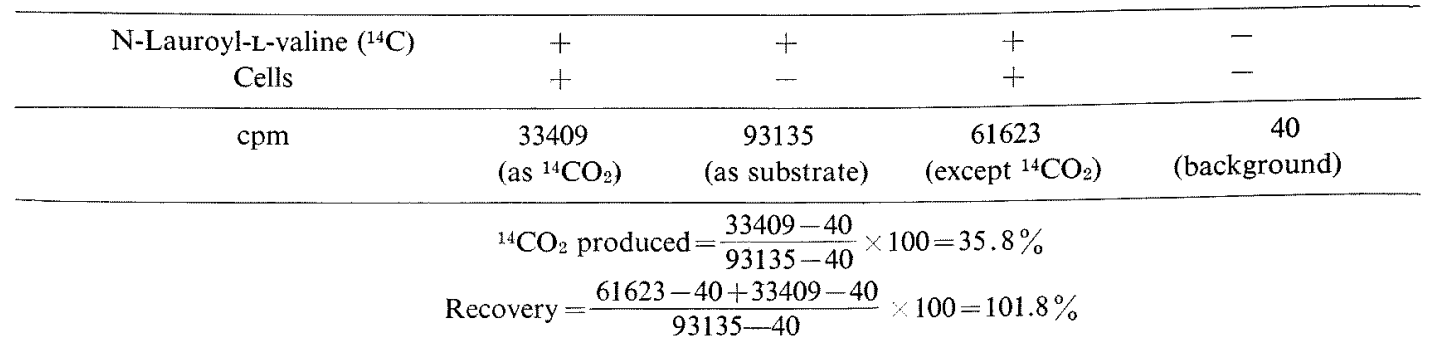

(peak 3 in graph B), and two peaks (peaks 1 and 2 in graph $\mathrm{A}$ ) were detected at the identical position with the retention times of authentic caprylic acid $\left(\mathrm{C}_{8}\right)$ and capric acid $\left(\mathrm{C}_{10}\right)$. Other peaks on the chromatogram A corresponded with those of the chromatogram B.

On the other hand valine was not detected in the incubation medium by microbial bioassay. Valine might be metabolized very rapidly by this strain. It seems that No. 5 was split to lauric acid and valine, and lauric acid was degraded to caprylic acid passing through capric acid by $\beta$-oxidation.

\section{5) Production of ${ }^{14} \mathrm{CO}_{2}$ from $\mathrm{No} .5-{ }^{14} \mathrm{C}$}

Cells of $P$ s. aeruginosa AJ2116 grown in the medium containing No. 5-Na were incubated with No. $5-{ }^{14} \mathrm{C}$ in a Warburg's manometer vessel. Radioactive carbon dioxide produced during the incubation was absorbed in $0.5 \mathrm{ml}$ of ethanolamine in a center well. Radioactivity of ${ }^{14} \mathrm{CO}_{2}$ was measured by a liquid scintillation counter. Results are shown in Table V. Radioactivity of ${ }^{14} \mathrm{CO}_{2}$ produced during incubation was $33409 \mathrm{cpm}$ and radioactivity except ${ }^{14} \mathrm{CO}_{2}$ was $61623 \mathrm{cpm}$. Therefore, ${ }^{14} \mathrm{CO}_{2}$ produced was $35.8 \%$ against initial radio activity, and recovery was $101.8 \%$.

$$
\begin{gathered}
{ }^{14} \mathrm{CO}_{2} \text { produced }=\frac{33409-40}{93135-40} \times 100=35.8 \% \\
\text { Recovery }=\frac{(61623-40+33409-40)}{93135-40} \\
\times 100=101.8 \%
\end{gathered}
$$

From these data it seems that $\mathrm{N}$-acyl linkage in No. 5 was cleft and lauric acid produced was degraded to $\mathrm{CO}_{2}$.

\section{DISCUSSION}

As shown in Tables I, II and III, No. 5-Na is degraded easily by many strains. It is suggested that No. 5 may not need any specific bacterial strains for its degradation under natural environments. Table IV indicates that the degradation of No. 5 was accelerated by the addition of $\left(\mathrm{NH}_{4}\right)_{2} \mathrm{SO}_{4}$ and $\left(\mathrm{NH}_{2}\right)_{2} \mathrm{CO}$. From this result, it is supposed that $\left(\mathrm{NH}_{4}\right)_{2} \mathrm{SO}_{4}$ or $\left(\mathrm{NH}_{2}\right)_{2} \mathrm{CO}$ added to soil as fertilizers may accelerate decomposition of No. 5 under natural conditions. Generally, it is said that the addition of fertilizers to the soil accelerates degradation of pesticides. As shown in Table $\mathrm{V}$ and Fig. $3, \mathrm{C}_{10}$ and $\mathrm{C}_{8}$ compounds were detected and the production of $\mathrm{CO}_{2}$ was detected as an end product. Valine might be very rapidly metabolized and incorporated into protein synthesis systems or deaminated as soon as produced. It is supposed that lauric acid was metabolized to capric and caprylic acids by $\beta$-oxidation.

Conventional pesticides are generally antidotal. However, as shown in Fig. 2, the enzymes or enzyme systems decomposing No. 5 may be recognized as constitutive. Therefore, it is suggested that the degradation of No. 5 is not performed antidotally. This is one of the important characters of No. 5. From all above-mentioned data, it is supposed that No. 5 may be rapidly degraded in soil, and the use of this compound will not bring about the possibility of environmental pollution.

Acknowledgements. The authors wish to express their sincere thanks to Dr. K. Komagata, Associate Professor of Tokyo University and Dr. A. Nakamura, Mr. A. Kamimura and Mr. Y. Ozawa of Central 
Research Laboratories, Ajinomoto Co, Inc., for their guidance to this work. Thanks are due to Mr. $\mathrm{Z}$. Terahara, Mr. I. Iwase and Mr. H. Morisawa of the Laboratories for their helps throughout this work. Our gratitude is due to Kaken Chemical Co., Ltd., for the supply of Blasticidin S.

\section{REFERENCES}

1) Y. Homma, T. Shida and T. Misato, Annales of the Phytopathological Society of Japan, in press.

2) S. Baba, H. Ido and T. Konishi, Presented at 90th Annual Meeting of the Pharmaceutical Society of Japan, Sapporo, 1970.

3) A. Kamimura, Agr. Biol. Chem., 37, 457 (1973). 